\title{
Absence of AIFIL contributes to cell migration and a poor prognosis of breast cancer
}

This article was published in the following Dove Press journal: OncoTargets and Therapy

Peipei Liu'

Wenhui $\mathrm{Li}^{2}$

Yuanyuan $\mathrm{Hu}^{\prime}$

Youhong Jiang'

'Molecular Oncology Laboratory of Cancer Research Institute, The First Hospital of China Medical University, Shenyang, People's Republic of China; ${ }^{2}$ Gastrointestinal Onco-Pathology Laboratory of Cancer Institute, The First Hospital of China Medical University, Shenyang II000I,

People's Republic of China
Correspondence: Youhong Jiang Molecular Oncology Laboratory of Cancer Research Institute, The First Hospital of China Medical University, No I55, Nanjingbei Street, Heping District, Shenyang I I000I, People's Republic of China Tel +8624832823I5 Email jiangyouhong2000@aliyun.com
Background: Breast cancer is the most common fatal cancer in women worldwide. Previous studies have demonstrated that allograft inflammatory factor 1 like (AIF1L) plays a key role in mammary tumorigenesis, although the mechanism involved remains unclear.

Purpose: The purpose of this study was to assess the clinicopathological and prognostic significance of AIF1L expression levels and biological function in breast cancer.

Patients and methods: We used immunohistochemistry to detect the expression of AIF1L in breast cancer. We also analyzed the expression of AIF1L in breast cancer using the Cancer Genome Atlas (TCGA) cohort and the Cancer Cell Line Encyclopedia (CCLE). Furthermore, both in vitro assays were used to determine the effect of AIF1L on malignant behavior in breast cancer cells.

Results: We detected AIF1L expression in tissue microarrays through immunohistochemistry and found that protein expression was significantly lower in BC tissues $(28.6 \%, 82 / 287)$ compared to tumor-adjacent tissues $(58.3 \%, 28 / 48)(P=0.007)$. Kaplan-Meier survival analysis revealed that disease-specific survival in BC patients with low AIF1L protein expression was significantly poorer compared to normal controls $(P=0.040)$. In the TCGA cohort, the AIFIL gene was downregulated and hypermethylated in tumor samples compared to normal controls. Bioinformatics analysis using CCLE predicted potential biological functions of AIF1L related to tight junctions, cell junctions and focal adhesion. Ectopic expression of AIF1L suppressed MDA-MB-231 migration and invasion. Further evidence confirmed that AIF1L overexpression suppressed cell spreading, altered cell shape and decreased protrusion formation, which was correlated with decreased focal adhesion kinase (FAK) and RhoA expression.

Conclusion: These findings suggest that AIF1L is a potential prognostic biomarker that plays a vital role in regulating the cytoskeleton in breast cancer.

Keywords: AIF1L, breast cancer, cytoskeleton, TCGA

\section{Introduction}

Breast cancer (BC) is the leading cause of cancer deaths among females worldwide, with an estimated $>500,000$ deaths occurring in $2012 .{ }^{1}$ As the incidence of $\mathrm{BC}$ is increasing rapidly, ${ }^{2}$ understanding the biological mechanisms involved and exploring novel targets are urgently needed.

EF-hand proteins are a large number of $\mathrm{Ca}_{2}+$-binding proteins. ${ }^{3,4}$ The EF-hand is a helix-loop-helix calcium-binding motif. They are involved in various biological processes, including inflammation, exocytosis, motility, apoptosis, tumor progression, and so on. ${ }^{3}$

Allograft inflammatory factor 1 like (AIF1L) is a protein with EF-hand motifs lacking bound $\mathrm{Ca}^{2+} .5$ AIF1L consists of 150 amino acids, and the sequence identity to AIF 1 is $60 \%$. AIF 1 protein is majorly expressed in the immune cells and participates in the inflammatory response and regulation. ${ }^{6}$ AIF1 can activate the monocyte/ macrophage, microglia, and lymphocyte immune cells, promote the expression of 
inflammatory mediators such as cytokines, chemokines, nitric oxide synthase, and boost immune cell proliferation and migration..$^{7-9}$ However, AIF1L is majorly expressed in the epithelial cells, such as renal glomerulus and renal tubules, endometrial gland, mammary ductal epithelial cells, glandular epithelium of epididymis, and vascular endothelial cells of spleen. ${ }^{10,11}$ Although AIF1 and AIF1L have remarkable sequence homology and structural similarity, they show a distinct pattern of tissue specific expression, so we speculated they have different biological functions.

AIF1L co-localizes with and crosslinks filamentous actin (F-actin) with subcortical filaments and localizes to membrane ruffle-like cellular projections and adhesion structures in a Shigella invasion model. ${ }^{5}$ AIF1L deficiency, which was functionally analyzed by siRNA silencing, was shown to result in significant loss and rearrangement of F-actin stress fibers, as shown by phalloidin staining, and led to cytoskeletal injury in immortalized human podocytes. ${ }^{12}$ So far, the potential roles of AIF1L in carcinogenesis have not been well characterized.

We studied AIF1L expression levels in BC, the effects of AIF1L on migration and invasion of BC cells, and characterized an AIF1L-related signaling pathway that influences cytoskeletal modifications.

\section{Patients and methods}

\section{Cell culture and engineering}

The MDA-MB-231 BC cell line was purchased from American Type Culture Collection. Cells were cultured in L15 medium (Hyclone) supplemented with 10\% fetal bovine serum (Thermo Fisher Scientific, MA USA). Adenoviruses purchased from Hanbio Biotechnology Co., Ltd. (Shanghai, People's Republic of China) were used to overexpress human AIF1L in MDA-MB-231 cells via transient transfection.

\section{Microarray and immunohistochemistry}

A total of 287 tissue samples from primary BC patients who underwent curative resection were collected at the First Hospital of China Medical University between December 2003 and April 2007. Tissue specimens were initially paraffin embedded and processed for routine histological evaluation. Written informed consent was obtained from each patient. Clinicopathologic data, including age, gender, World Health Organization histological type, and TNM stage, as well as estrogen receptor(ER), progesterone receptor (PR), Ki67, and human epidermal growth factor receptor 2 (HER2) expression, were collected. A total of $259 \mathrm{BC}$ patients with at least a 5-year follow-up were included in prognosis analysis. This study was conducted in accordance with the Declaration of Helsinki and approved by the Ethics Committee of China Medical University. All samples were evaluated by two experienced pathologists to confirm diagnosis. AIF1L expression levels were detected using a two-step immunohistochemical method (Beijing Zhongshan Golden Bridge Biotechnology Company, Beijing, People's Republic of China). Rabbit polyclonal antibodies against human AIF1L were purchased from Abcam (Shanghai, People's Republic of China). Tissue microarray slides were deparaffinized in xylene and hydrated with graded alcohol before incubation with $3 \% \mathrm{H}_{2} \mathrm{O}_{2}$ and heat-induced antigen retrieval. Slides were incubated with primary antibodies overnight at $4{ }^{\circ} \mathrm{C}$ and stained using a two-step detection system; counterstaining was performed with hematoxylin. All procedures were carried out according to the manufacturers' instructions. For negative controls, sections were treated with $0.01 \mathrm{~mol} / \mathrm{L}$ PBS instead of primary antibodies.

Cells expressing AIF1L proteins had visible brown granules in the cytoplasm and membrane. Immunostaining intensities were evaluated by two independent pathologists in a blinded manner. The scoring system was based on the intensity and extent of staining. Expression levels were classified as low and high, as previously described. ${ }^{13}$

\section{Biological informatics analysis for AIFIL expression and methylation}

The Cancer Genome Atlas (TCGA) RNA-sequencing database (level 3 data) included 1,100 BC samples and 112 normal controls. To identify an association between AIF1L methylation and expression, we also downloaded HumanMethylation450 data (level 3 data) for breast tumor tissues and adjacent non-tumor tissues from TCGA. The association between AIF1L mRNA expression and DNA methylation was determined by calculating the Spearman correlation coefficient. The total number of matched samples was 868. Beta-value statistics were used to measure methylation levels. ${ }^{14}$ AIF1L protein expression in BC was confirmed according to The Human Protein Atlas. ${ }^{50}$

\section{Cancer Cell Line Encyclopedia (CCLE) data analysis}

The CCLE project is an effort to conduct detailed genetic characterization of a large panel of human cancer cell lines. CCLE provides public access analysis and visualization of DNA copy number, mRNA expression, mutation data, and more for $\sim 1,000$ cancer cell lines, ${ }^{15,16}$ including $52 \mathrm{BC}$ cells that were analyzed in the present study. We withdrew AIF1L co-expression genes from the CCLE database with $\mathrm{R}$ language, then used DAVID Bioinformatics Resources 6.7 
(National Institute of Allergy and Infectious Diseases, MD, USA, National Institutes of Health [NIH]) for gene ontology and the Kyoto Encyclopedia of Genes and Genomes enrichment analyses (https://david.abcc.ncifcrf.gov/). ${ }^{17,18}$ Data from the BC cell lines were also evaluated using gene set enrichment analysis (GSEA) and GSEA2-2.2.3 software. AIF1L expression levels were dichotomized into two groups to annotate phenotype with msigdb.v5.2.symbols gene sets. ${ }^{19,20}$ All other parameters were set to default values. ${ }^{21,22}$

\section{Transwell migration and invasion assays}

Migration and invasion assays were performed as previously described. ${ }^{23}$ For the invasion assays, $50 \mu \mathrm{L}$ Matrigel (Corning, NY, USA) was added to the well inserts and incubated overnight. Cells $\left(5 \times 10^{4}\right)$ were suspended in serum-free culture media and seeded into Transwell inserts. Plates on the bottom received complete media and were incubated at $37^{\circ} \mathrm{C}$ for 24 hours. Unmigrated cells were removed using cotton swabs. Cells were fixed with 4\% paraformaldehyde and stained with a $1 \%$ crystal violet solution (Sigma-Aldrich St. Louis, MO, USA). For each plate, five random fields were counted at $10 \times$ magnification. Images were processed with ImageJ software to count the number of cells in the migration and invasion assay.

\section{Protein extraction and immunoblots}

Cells were solubilized in radioimmunoprecipitation assay lysis buffer with protease inhibitors. Equal amounts of protein were resolved by sodium dodecyl sulfate-polyacrylamide gel electrophoresis and transferred to polyvinylidene fluoride membranes. Membranes were blocked with 5\% nonfat milk for 2 hours and incubated overnight at $4{ }^{\circ} \mathrm{C}$ with primary antibodies. Proteins were detected using an enhanced chemiluminescence kit and photographed using the ChemiDoc MP System (Bio-Rad Laboratories Inc., Hercules, CA, USA). Rabbit monoclonal antibodies against human FAK and RHOA were purchased from Abcam.

\section{Cell spreading assays}

A cell spreading assay was performed as previously described. ${ }^{24}$ MDA-MB-231 controls and AIF1L-overexpressing cells were resuspended in serum-free medium. A total of $5 \times 10^{4}$ cells were added to Matrigel-coated glass coverslips. Sixty minutes after plating, cells were fixed with $4 \%$ paraformaldehyde for 20 minutes at room temperature. After washing with PBS, $0.1 \%$ Triton X-100 (in PBS) was added for 10 minutes at room temperature. Cells were blocked with $10 \%$ normal goat serum for 10 minutes at room temperature. Cells were incubated with $0.5 \mu \mathrm{M}$ tetramethylrhodamine-phalloidin (Sigma-
Aldrich) for 1 hour at room temperature and counterstained with 4',6-diamidino-2-phenylindole to visualize nuclei. Coverslips were imaged using epifluorescence microscopy (Nikon Corporation, Tokyo Japan). Images were processed with ImageJ software to measure the areas of the cell and nucleus. Circularity and aspect ratio were used to measure cell shape as previously described. ${ }^{25,26}$ Both cell circularity and aspect ratio were used to measure the roundness of a cell. Over 50 cells were quantified per sample. The experiment was performed in three technical replicates.

\section{Statistical analysis}

Statistical analysis was performed with SPSS 17.0 (SPSS Inc., Chicago, IL, USA) or R language. Continuous data are shown as the mean $\pm \mathrm{SD}$ or standard error of mean for normally distributed data. Chi-squared test or Fisher's exact test was used to compare different groups. Log-rank testing was used to assess the associations between disease-free survival and disease covariates to identify prognostic factors. Two sided $P<0.05$ was considered statistically significant.

\section{Results}

Downregulation of AIFIL expression in BC In this cohort, positive rates of AIF1L protein expression in BC $(28.6 \%, 82 / 287)$ were significantly lower than in tumoradjacent tissues $(58.3 \%, 28 / 48 ; P=0.007$; Figure $1 \mathrm{~A}$ and $\mathrm{B})$. AIF1L mRNA expression was also significantly decreased in BC compared with controls in TCGA (Figure 1E). Methylation of gene $\mathrm{CpG}$ island promoters is a generally accepted mechanism for silencing expression. Strong associations between methylation patterns and expression have been reported.$^{27}$ HumanMethylation450 BeadChip (450 K) is based on the Illumina Technology and contains 482,421 probes, targeting $99 \%$ of genes and $96 \%$ of $\mathrm{CpG}$ island regions. ${ }^{28}$ Spearman correlation coefficients were calculated, which showed a negative correlation between the expression and methylation of AIF1L genes (Figure 1G). Notably, AIF1L genes were hypermethylated in tumor samples compared to normal controls (Figure 1F). Using data from Protein Atlas, AIF1L protein staining against HPA020522 and HPA056852 antibodies (rabbit polyclonal antibody; Sigma-Aldrich) was visible in both the cytoplasm and membranes. Normal breast glandular cells showed higher staining intensity for HPA020522 and medium staining intensity for HPA056852. Results of staining BC cells are as follows: medium (2/12), low $(2 / 12)$, and not detected (8/12) for HPA020522 and medium (4/12), low (5/12), and not detected (3/12) for HPA056852. 

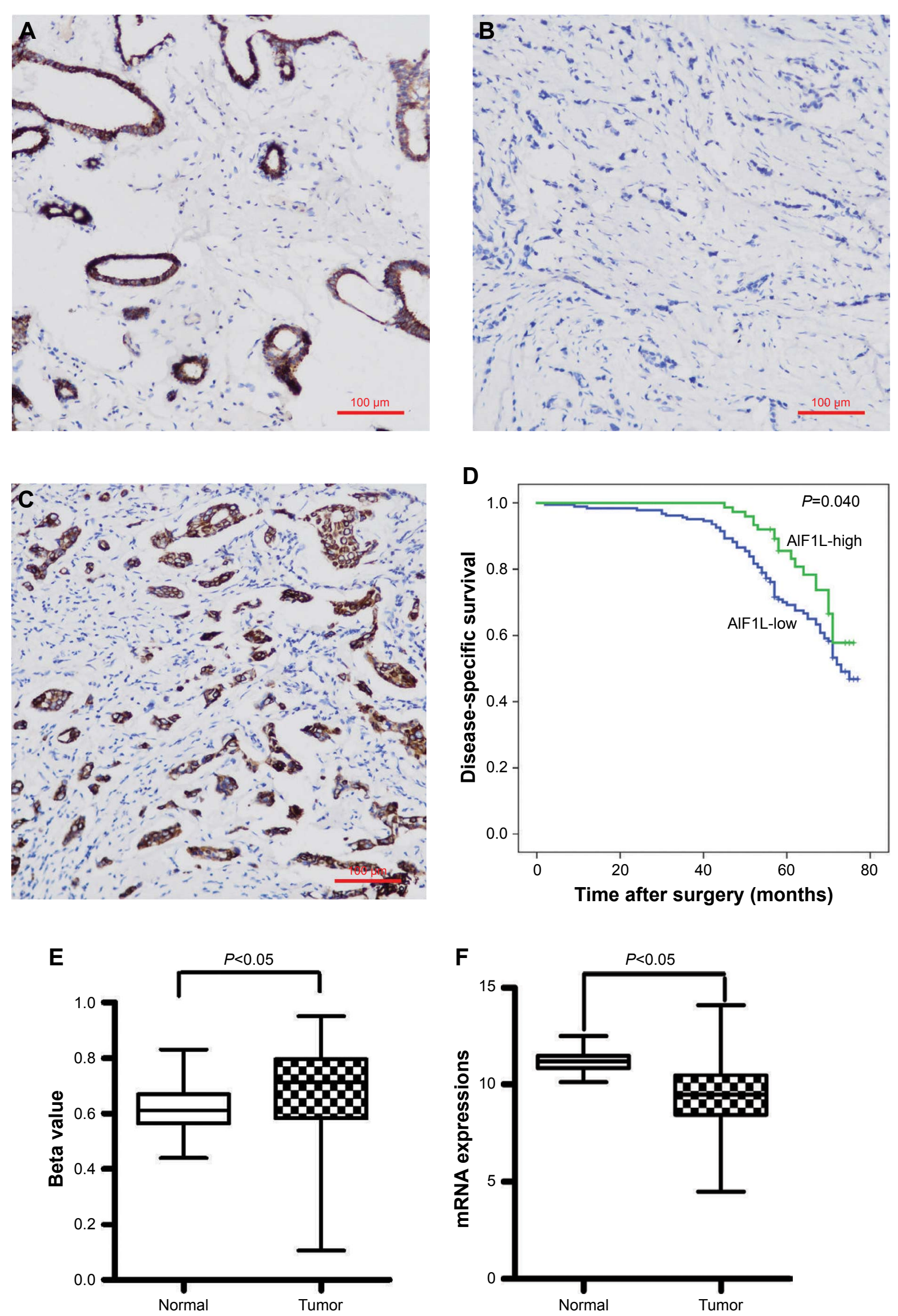


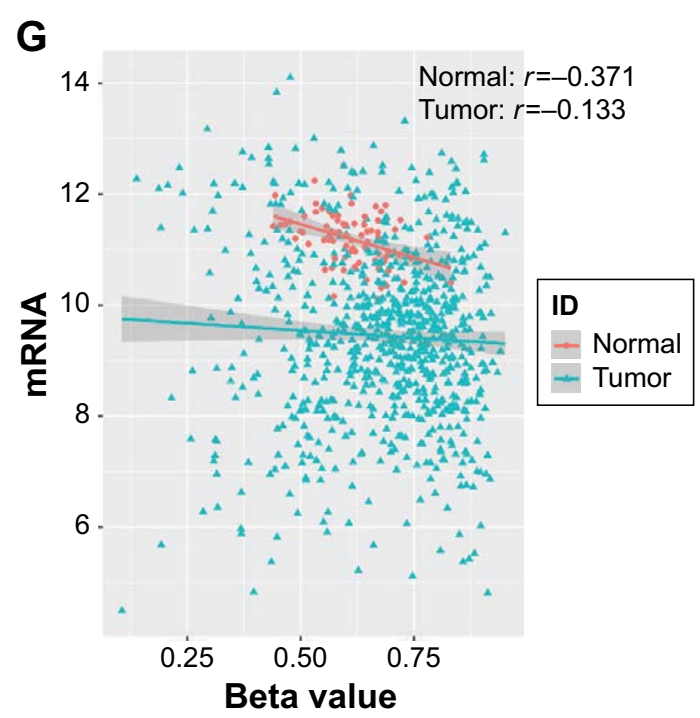

Figure I AIFIL expression levels in 287 surgical tissue samples from breast cancer patients were assessed by immunohistochemistry.

Notes: (A) Positive AIFIL staining in surrounding non-tumor areas; (B) Negative AIFIL staining; (C) Positive AIFIL staining. (D) Low AIFIL expression is associated with poor survival in breast cancer patients, $P=0.040$. AIFIL expression levels from TCGA. (E) AIFIL methylation levels were higher in breast cancer cells compared to normal controls. (F) AIFIL mRNA expression was lower in breast cancer cells compared to normal controls, both $P<0.05$ ( $P$-value were calculated by t-test). (G) Negative correlation between AIFIL methylation levels and mRNA expression, $r=-0.37$ in normal samples; $r=-0.133$ in breast cancer samples (spearman correlation coefficient).

\section{Correlation between AIFIL levels and clinicopathologic factors}

Positive rates of AIF1L expression in $\mathrm{HER} 2^{+}$were significantly higher than HER2- $(P=0.038)$. AIF1L expression was lower in triple-negative breast cancer (TNBC) compared with non-TNBC. No significant differences in AIF1L levels were detected in relation to age, T\&N stage subtype, ER and PR status, and Ki67 status (Table 1).

\section{Low expression of AIFIL correlates with shorter disease-free survival in BC patients}

Patients with low AIF1L expression showed a poor diseasefree survival rate $(P=0.040$; Figure 1$)$. The hazard ratio (HR) for AIF1L protein expression was 0.610 (95\% CI, $0.377-0.987 ; P=0.044$ ) in the AIF1L-positive group (univariate analysis). Seven baseline variables (age, T\&N stage subtype, ER status, PR status, HER2 status, and Ki67 status) were evaluated with AIF1L expression using Cox regression analysis. The HR for AIF1L was not significantly changed $(\mathrm{HR}=0.724$ [95\% CI, 0.404-1.298]; $P=0.278)$.

\section{Potential biological functions of AIFIL}

To explore the unique roles of AIF1L, we identified 196 AIF1L co-expression genes from the CCLE database with $R$ language by setting the Pearson coefficient $>0.6$. After performing gene ontology and the Kyoto Encyclopedia of Genes and Genomes pathway analysis using DAVID tools, ${ }^{17}$ the most
Table I Clinicopathologic characteristics and AIFIL protein expression

\begin{tabular}{|c|c|c|c|c|}
\hline Characteristics & $\mathbf{n}$ & AIF I L-low & $\begin{array}{l}\text { AIF IL-high } \\
(\mathrm{n}, \%)\end{array}$ & $P$-value \\
\hline Age (years) & & & & 0.056 \\
\hline$\leq 45$ & 91 & 72 & $19(20.9)$ & \\
\hline$>45$ & 195 & 133 & $62(31.8)$ & \\
\hline T stage & & & & 0.35 \\
\hline TI & 97 & 65 & $32(33.0)$ & \\
\hline $\mathrm{T} 2$ & 135 & 101 & $34(25.2)$ & \\
\hline T3 & 6 & 5 & I (16.7) & \\
\hline $\mathrm{N}$ stage & & & & 0.331 \\
\hline No & 174 & 130 & $44(25.3)$ & \\
\hline $\mathrm{NI}$ & 61 & 38 & $23(37.7)$ & \\
\hline N2 & 27 & 19 & $8(29.6)$ & \\
\hline N3 & 17 & 12 & $5(29.4)$ & \\
\hline ER status & & & & 0.339 \\
\hline Negative & 74 & 56 & $18(24.3)$ & \\
\hline Positive & 202 & $|4|$ & $61(30.2)$ & \\
\hline PR status & & & & 0.653 \\
\hline Negative & 78 & 57 & $21(26.9)$ & \\
\hline Positive & 199 & 140 & $59(29.6)$ & \\
\hline HER2 status & & & & 0.038 \\
\hline Negative & 246 & 181 & $65(26.4)$ & \\
\hline Positive & 21 & II & $10(47.6)$ & \\
\hline Ki67 status & & & & 0.503 \\
\hline$\leq 14 \%$ & 201 & 144 & $57(28.4)$ & \\
\hline$>14 \%$ & 31 & 24 & $7(22.6)$ & \\
\hline \multicolumn{5}{|l|}{ Molecular subtype } \\
\hline Luminal A* & 158 & 113 & $45(28.5)$ & $0.052(*$ vs $\$)$ \\
\hline Luminal $\mathrm{B}^{\#}$ & 29 & 19 & $10(34.5)$ & 0.038 (\# vs \$) \\
\hline $\mathrm{TNBC}^{\$}$ & 38 & 33 & $5(13.2)$ & \\
\hline HER2+ \& & 12 & 6 & $6(50)$ & 0.007 (\& vs \$) \\
\hline
\end{tabular}

Notes: *Luminal A; \#Luminal B; ${ }^{\text {TTNBC; }}{ }^{\star} \mathrm{HER} 2+$

Abbreviations: ER, estrogen receptor; HER2, human epidermal growth factor receptor 2; PR, progesterone receptor; TNBC, triple-negative breast cancer. 
enriched biological themes were related to tight junctions and cell junctions (Figure 2A). To further assess the biological function of AIF1L in breast tumorigenesis, we applied GSEA to BC cells from the CCLE. Top 50 differentially expressed genes between low vs high expressions of AIF1L are shown in Table S1. Downregulation of AIF1L was significantly correlated with focal adhesion (FA; Figure 2B). Genes in the FA pathway were identified by GSEA (Figure 2C; Table S2).

\section{AIFIL inhibits migration and invasion of MDA-MB-23 I BC cells}

The mRNA expression levels of BC cells in CCLE are shown Figure S1. AIF1L expression of MDA-MB-231 cells was lower than that of immortalized epithelial HMEL cells. To further investigate the effect of AIF1L overexpression on cell migration and invasion, the Transwell migration and invasion assays were performed. Transwell migration and invasion assays showed that transient overexpression of AIF1L significantly suppressed migration and invasion compared to the control group $(P<0.05$; Figure 3).

\section{AIFIL inhibits MDA-MB-23 I cell spreading and mediates focal adhesion kinase (FAK) levels involved in ROCK signaling}

Cell migration and spreading are initiated by global reorganization of the actin cytoskeleton and extending actin polymerization-driven lamellipodium protrusions of the cell membrane..$^{29,30}$ Thirty minutes after plating, cells overexpressing AIF1L spread less efficiently than the control cells (Figure 4A, B, E) and were less elongated, as indicated by an increase in circularity and decrease in aspect ratio (Figure 4C-F). Elongated cells showed actin remodeling toward the membrane, which is equivalent to the formation of ruffles and pseudopodia (Figure 4D).
A

\begin{tabular}{|c|c|c|c|c|}
\hline Annotation cluster & $\begin{array}{l}\text { Enrichment score: } \\
5.3263843074630515\end{array}$ & Count & $\%$ & $P$-value \\
\hline Category & Term & & & \\
\hline UP_KEYWORDS & Tight junction & 10 & 5.46 & $6.63 \mathrm{E}-08$ \\
\hline GOTERM_CC_DIRECT & GO:0005923 tight junction & 11 & 6.01 & $1.29 \mathrm{E}-07$ \\
\hline GOTERM_BP_DIRECT & $\begin{array}{l}\text { GO:0070830 tight junction } \\
\text { assembly }\end{array}$ & 6 & 3.27 & 1.32E-05 \\
\hline UP_KEYWORDS & Cell junction & 18 & 9.83 & $1.01 \mathrm{E}-04$ \\
\hline KEGG_PATHWAY & hsa04530 tight junction & 8 & 4.37 & $2.05 \mathrm{E}-04$ \\
\hline
\end{tabular}

B

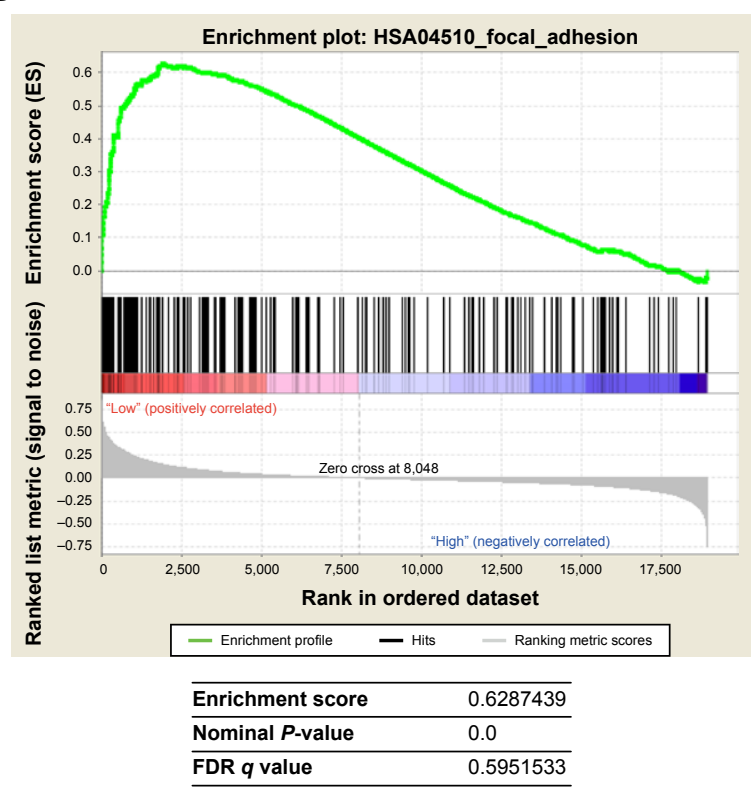

C

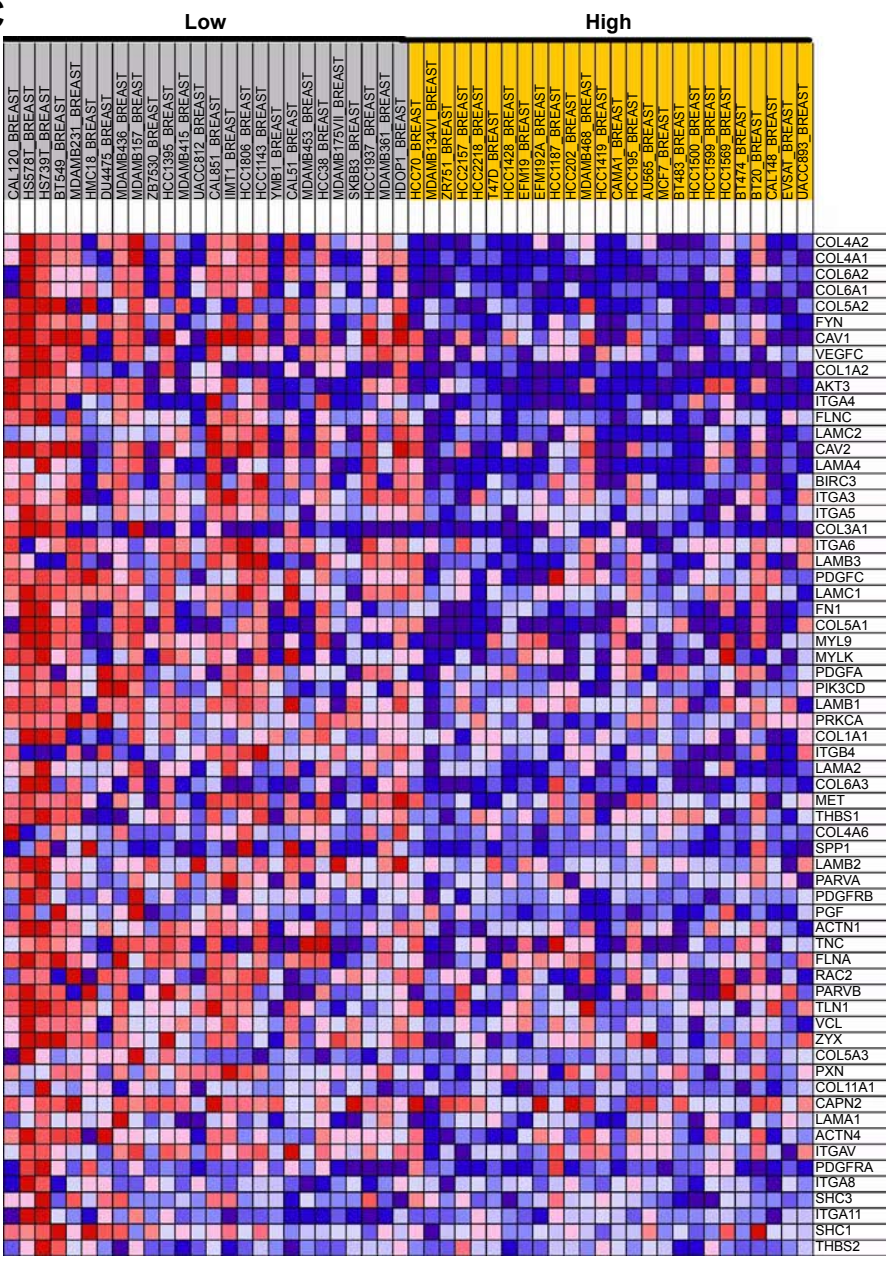

Figure 2 Gene set enrichment analysis (GSEA) and DAVID functional annotation clustering using public repository data from CCLE.

Notes: (A) DAVID functional annotation clustering for AIFIL co-expression genes. (B) GSEA for HSA045I0_FOCAL_ADHESION, which is related to low AIFIL expression. (C) Genes in the HSA045I0_FOCAL_ADHESION pathway are upregulated in breast cancer cells with low AIFIL levels.

Abbreviation: FDR, false discovery rate. 

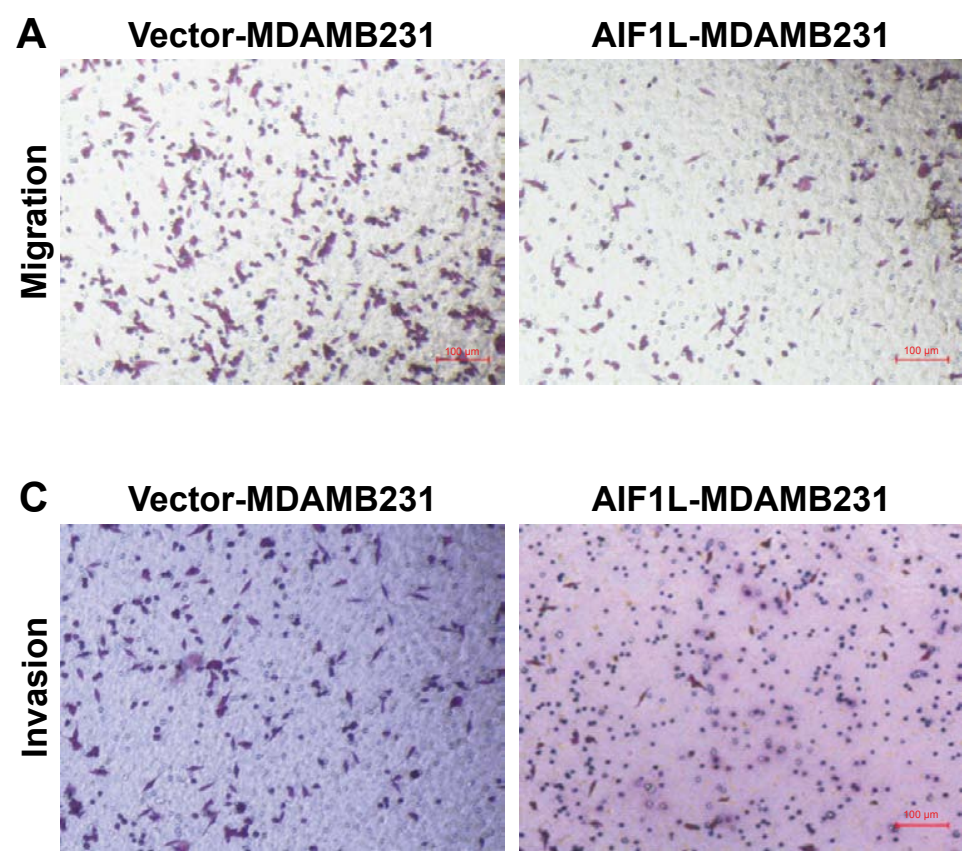
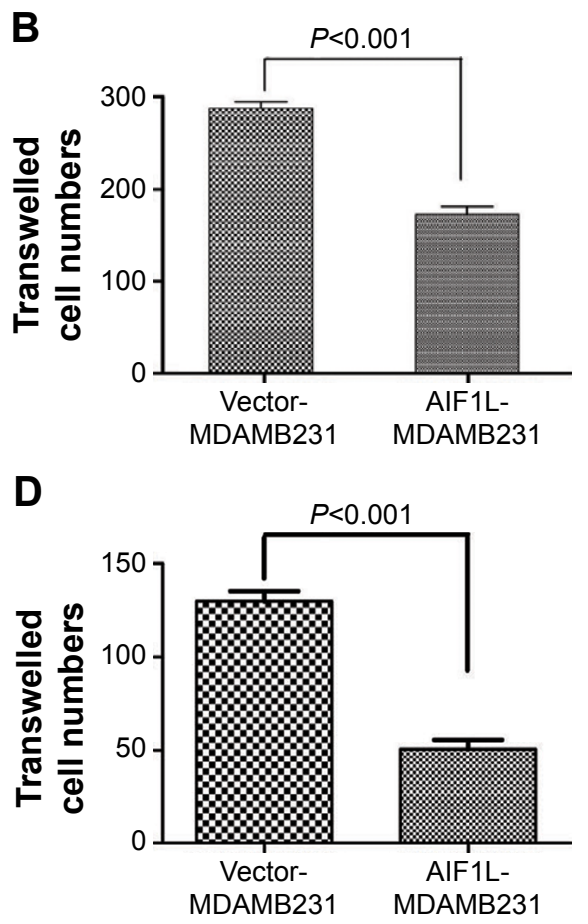

Figure 3 Decreased migration and invasion of MDAMB-23I cells with transient AIFIL overexpression.

Notes: Cell migration $(\mathbf{A})$ and invasion $(\mathbf{C})$ were detected using transwell assays. Representative images are shown following staining with crystal violet. Quantification of cell migration (B) and invasion (D) are also shown.

FAK is a nonreceptor tyrosine kinase that plays a central role in cell migration through regulation of lamellipodial formation and FAs. ${ }^{31,32}$ Increased FAK expression has been correlated with increased clinical progression in BC. ${ }^{33,34}$ Therefore, we assessed FAK expression in AIF1L-overexpressing MDA-MB-231 cells and controls and showed that AIF1L led to increased inhibition of FAK expression (Figure 4G). FAK is involved with activators and/or inhibitors of the small GTPase RhoA that enable FAK activity to be connected to alterations in polymerization of actin filaments during tumor cell adhesion and motility. ${ }^{35,36}$ RhoA expression was also inhibited by AIF1L overexpresssion in MDA-MB-231 cells (Figure 4G).

\section{Discussion}

In the present study, we analyzed the expression and clinicopathologic significance of AIF1L in BC. Low AIF1L protein expression was observed in $71.4 \%$ of $\mathrm{BC}$ samples in this cohort. AIF1L mRNA expression was also lower in patients with BC in TCGA cohort. Furthermore, AIF1L protein expression in $\mathrm{BC}$ was confirmed from Protein Atlas. Thus, AIF1L expression is downregulated in BC. Furthermore, we integrated AIF1L DNA methylation and gene expression from TCGA database and found that AIF1L downregulation may be due to hypermethylation of the promoter. Given that the Spearman correlation coefficient was very low, particularly with tumor tissues, we searched ${ }^{51}$ and found that no genetic alterations in AIF1L were reported in 977 sequenced patients from TCGA. We hypothesized that in addition to methylation, there might be some other reason for AIF1L downregulation, such as a posttranscriptional regulation mechanism rather than gene mutation. Low AIF1L expression was detected in TNBC and was correlated with a poor postoperative disease-specific survival. TNBC accounts for $\sim 15 \%-20 \%$ of $\mathrm{BCs}$ and is defined by the absence of ER $\alpha$, PR, and HER 2 amplification, which is resistant to conventional chemotherapy, lack of targeting agents and is often associated with a poor prognosis. ${ }^{37,38}$ AIF1L could be a unique molecular target of TNBCs.

CCLE data analysis revealed AIF1L-related pathways, including cell junction, tight junction, and FA. Of the AIF1L co-expression genes, $\mathrm{CDH} 1$ (cadherin 1, E-cadherin) is a major component of intercellular junctions, and loss of its expression has been shown to reduce $\mathrm{BC}$ invasion and metastasis. ${ }^{39,40}$ FAs connect the cytoskeleton and extracellular matrix (ECM). Interplay between the actin cytoskeleton and FA dynamics results in a balance between adhesion and contraction, which greatly influences cell migration. ${ }^{35,41}$

Although AIF1L induces cytoskeletal rearrangements in HeLa cells and podocytes, whether it is involved in BC progression, especially in TNBCs, is not understood. The data reported herein show that ectopic AIF1L expression suppresses MDA-MB-231 BC cell motility and invasion 

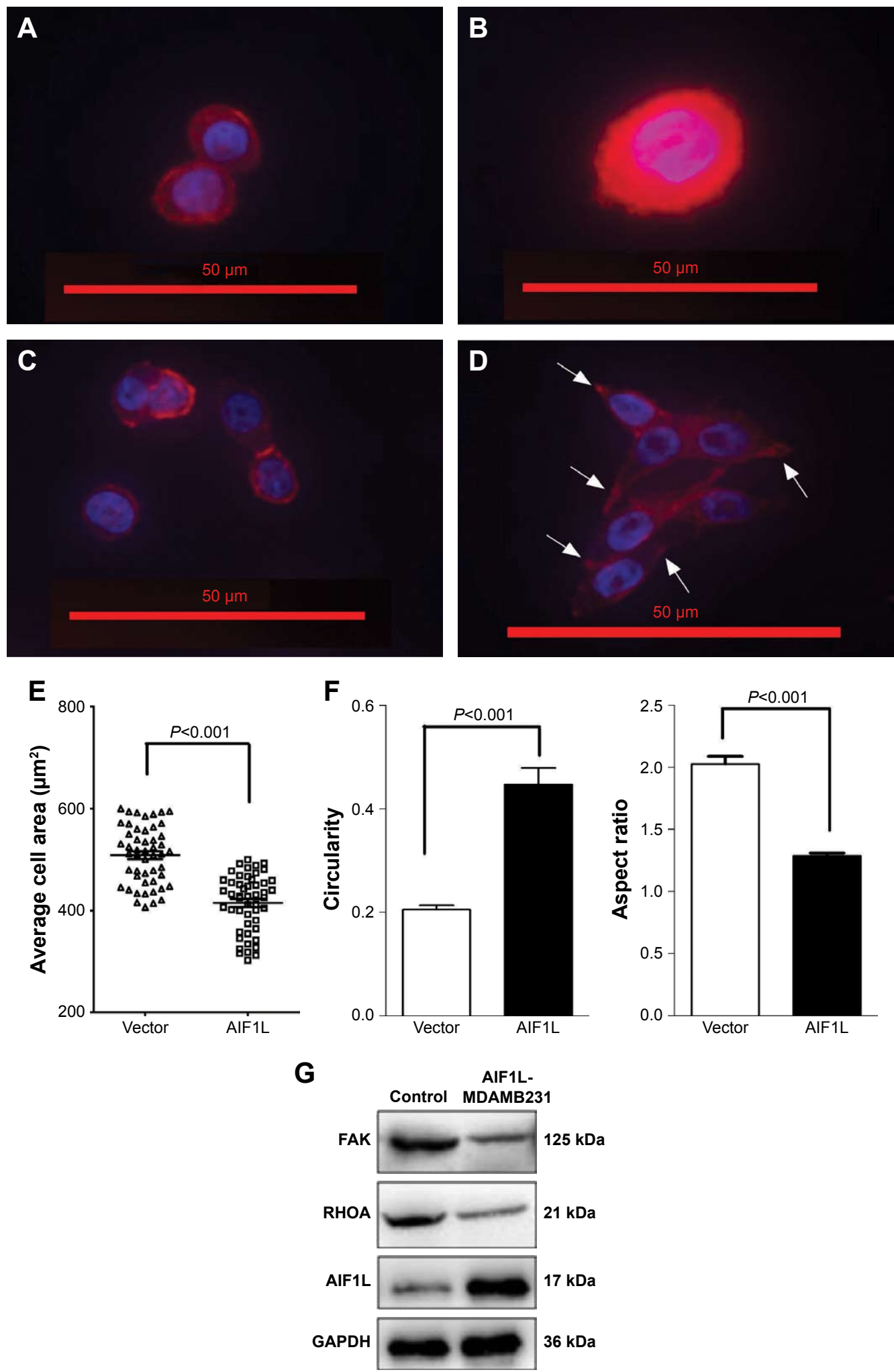

Figure 4 AIFIL inhibits cell spreading and alters cell morphology.

Notes: (A, B) AIFIL overexpression in MDA-MB-23I cells resulted in slower spreading on a matrigel coated surface compared with controls. Representative images of cells stained using TRITC-phalloidin and DAPI to show the nuclei. (C, D) Example images of rounded cells and elongated cells. (E) Average area of cells \pm SEM from a minimum of 50 cells for each treatment. (F) Cell circularity and aspect ratio were measured from at least 50 cells for AIFIL overexpression in MDA-MB-23I cells and controls. AIFIL increased circularity and reduced the aspect ratio on a matrigel coated surface compared with controls. Arrows show cell protrusions. Statistical significance was evaluated using the two-sample t-test: $* P<0$.05. (G) A representative Western blot demonstrating downregulation of FAK and RHOA expression in MDA-MB-23I cells overexpressing AIFIL. 
by inducing cytoskeletal modifications, which are achieved through FAK/RHOA signaling. High FAK expression was correlated with shorter overall survival and progression-free survival in patients with $\mathrm{BC}$, especially in TNBC patients with high FAK expression. ${ }^{42,43}$ RhoA protein is also overexpressed in $\mathrm{BC} .{ }^{44,45}$ The actin cytoskeleton is linked to invasive and metastatic phenotypes of malignant cancer cells. Cell migration is driven by cycles of actin polymerization and is initiated by cell membrane protrusions called filopodia, lamellipodia, and invadopodia. ${ }^{46}$ These protrusions are stabilized by adhesions linking the actin cytoskeleton to ECM proteins and actomyosin contraction. ${ }^{35,47}$ Located on the inner face of the cell membrane, FAs form a vital link between the ECM and the cytoskeleton. Interplay between F-actin contractile forces and FA dynamics greatly influences cell migration capacity. ${ }^{35}$ Integrin receptor binding to ECM proteins is one of the strongest activators of FAK. ${ }^{48,49}$ In the present study, MDAMB-231 cells transfected with AIF1L showed decreased cell spreading, more circular cell shape, and formation of fewer protrusions. GSEA also found low AIF1L expression correlated with high expression of collagens such as COL4, COL6, COL5, and COL1. AIF1L may inhibit FAK/RHOA expression through interfering in cell-ECM signaling. But the accurate molecular mechanism needs further research. These results support a role for AIF1L in regulating actin remodeling associated with cell migration.

\section{Conclusion}

This study evaluated AIF1L expression in BC and found that AIF1L downregulation may predict a poor prognosis. AIF1L suppresses $\mathrm{BC}$ migration and invasion through regulating actin remodeling, which is dependent on FAK/RHOA signaling. However, additional mechanisms that influence AIF1L regulation of the actin cytoskeleton should be identified and characterized in the future.

\section{Disclosure}

The authors report no conflicts of interest in this work.

\section{References}

1. Torre LA, Bray F, Siegel RL, Ferlay J, Lortet-Tieulent J, Jemal A. Global cancer statistics, 2012. CA Cancer J Clin. 2015;65(2):87-108.

2. Ginsburg O, Bray F, Coleman MP, et al. The global burden of women's cancers: a grand challenge in global health. Lancet. 2017;389(10071): 847-860.

3. Kawasaki H, Kretsinger RH. Structural and functional diversity of EFhand proteins: Evolutionary perspectives. Protein Sci. 2017;26(10): 1898-1920.

4. Clapham DE. Calcium signaling. Cell. 2007;131(6):1047-1058.

5. Schulze JO, Quedenau C, Roske Y, et al. Structural and functional characterization of human Iba proteins. FEBS J. 2008;275(18):4627-4640.
6. Ito D, Imai Y, Ohsawa K, Nakajima K, Fukuuchi Y, Kohsaka S Microglia-specific localisation of a novel calcium binding protein, Iba1. Brain Res Mol Brain Res. 1998;57(1):1-9.

7. Yang ZF, Ho DW, Lau CK, et al. Allograft inflammatory factor-1 (AIF-1) is crucial for the survival and pro-inflammatory activity of macrophages. Int Immunol. 2005;17(11):1391-1397.

8. Autieri MV, Kelemen S, Thomas BA, Feller ED, Goldman BI, Eisen HJ. Allograft inflammatory factor-1 expression correlates with cardiac rejection and development of cardiac allograft vasculopathy. Circulation. 2002;106(17):2218-2223.

9. Cai H, Zhu XD, Ao JY, Jy A, et al. Colony-stimulating factor-1-induced AIF1 expression in tumor-associated macrophages enhances the progression of hepatocellular carcinoma. Oncoimmunology. 2017;6(9): e1333213.

10. Uhlen M, Zhang C, Lee S, et al. A pathology atlas of the human cancer transcriptome. Science. 2017;357(6352):eaan2507.

11. Uhlén M, Fagerberg L, Hallström BM, et al. Proteomics. Tissue-based map of the human proteome. Science. 2015;347(6220):1260419.

12. Lu Y, Ye Y, Bao W, et al. Genome-wide identification of genes essential for podocyte cytoskeletons based on single-cell RNA sequencing. Kidney Int. 2017;92(5):1119-1129.

13. Zhang H, Luo M, Jin Z, et al. Expression and clinicopathological significance of FSIP1 in breast cancer. Oncotarget. 2015;6(12): 10658-10666.

14. Du P, Zhang X, Huang CC, et al. Comparison of Beta-value and M-value methods for quantifying methylation levels by microarray analysis. BMC Bioinformatics. 2010;11:587.

15. Barretina J, Caponigro G, Stransky N, et al. The Cancer Cell Line Encyclopedia enables predictive modelling of anticancer drug sensitivity. Nature. 2012;483(7391):603-607.

16. Shiau CK, Gu DL, Chen CF, Lin CH, Jou YS. IGRhCellID: integrated genomic resources of human cell lines for identification. Nucleic Acids Res. 2011;39(Database issue):D520-D524.

17. Huang da W, Sherman BT, Lempicki RA. Systematic and integrative analysis of large gene lists using DAVID bioinformatics resources. Nat Protoc. 2009;4(1):44-57.

18. Huang da W, Sherman BT, Lempicki RA. Bioinformatics enrichment tools: paths toward the comprehensive functional analysis of large gene lists. Nucleic Acids Res. 2009;37(1):1-13.

19. Liberzon A, Subramanian A, Pinchback R, Thorvaldsdóttir H, Tamayo P, Mesirov JP. Molecular signatures database (MSigDB) 3.0. Bioinformatics. 2011;27(12):1739-1740.

20. Liberzon A, Birger C, Thorvaldsdóttir H, Ghandi M, Mesirov JP, Tamayo P. The Molecular Signatures Database (MSigDB) hallmark gene set collection. Cell Syst. 2015;1(6):417-425.

21. Subramanian A, Tamayo P, Mootha VK, et al. Gene set enrichment analysis: a knowledge-based approach for interpreting genome-wide expression profiles. Proc Natl Acad Sci U S A. 2005;102(43):15545-15550.

22. Mootha VK, Lindgren CM, Eriksson KF, et al. PGC-1alpha-responsive genes involved in oxidative phosphorylation are coordinately downregulated in human diabetes. Nat Genet. 2003;34(3):267-273.

23. Xiong X, Wang Y, Liu C, et al. Heat shock protein $90 \beta$ stabilizes focal adhesion kinase and enhances cell migration and invasion in breast cancer cells. Exp Cell Res. 2014;326(1):78-89.

24. Humphries MJ. Cell adhesion assays. Methods Mol Biol. 2009;522: 203-210.

25. Carey SP, Kraning-Rush CM, Williams RM, Reinhart-King CA. Biophysical control of invasive tumor cell behavior by extracellular matrix microarchitecture. Biomaterials. 2012;33(16):4157-4165.

26. Gehler S, Compere FV, Miller AM. Semaphorin 3A increases FAK phosphorylation at focal adhesions to modulate MDA-MB-231 cell migration and spreading on different substratum concentrations. Int $J$ Breast Cancer. 2017;2017:9619734.

27. Vanderkraats ND, Hiken JF, Decker KF, Edwards JR. Discovering high-resolution patterns of differential DNA methylation that correlate with gene expression changes. Nucleic Acids Res. 2013;41(14): 6816-6827. 
28. Bibikova M, Barnes B, Tsan C, et al. High density DNA methylation array with single CpG site resolution. Genomics. 2011;98(4):288-295.

29. Parsons JT, Horwitz AR, Schwartz MA. Cell adhesion: integrating cytoskeletal dynamics and cellular tension. Nat Rev Mol Cell Biol. 2010;11(9):633-643.

30. Zimerman B, Volberg T, Geiger B. Early molecular events in the assembly of the focal adhesion-stress fiber complex during fibroblast spreading. Cell Motil Cytoskeleton. 2004;58(3):143-159.

31. Mitra SK, Hanson DA, Schlaepfer DD. Focal adhesion kinase: in command and control of cell motility. Nat Rev Mol Cell Biol. 2005; 6(1):56-68.

32. Mitra SK, Schlaepfer DD. Integrin-regulated FAK-Src signaling in normal and cancer cells. Curr Opin Cell Biol. 2006;18(5):516-523.

33. Almstedt K, Sicking I, Battista MJ, et al. Prognostic significance of focal adhesion kinase in node-negative breast cancer. Breast Care. 2017;12(5):329-333.

34. Lark AL, Livasy CA, Dressler L, et al. High focal adhesion kinase expression in invasive breast carcinomas is associated with an aggressive phenotype. Mod Pathol. 2005;18(10):1289-1294.

35. Fife CM, Mccarroll JA, Kavallaris M. Movers and shakers: cell cytoskeleton in cancer metastasis. Br J Pharmacol. 2014;171(24):5507-5523.

36. Lim Y, Lim ST, Tomar A, et al. PyK2 and FAK connections to p190Rho guanine nucleotide exchange factor regulate RhoA activity, focal adhesion formation, and cell motility. J Cell Biol. 2008;180(1): 187-203.

37. Papa A, Caruso D, Tomao S, Rossi L, Zaccarelli E, Tomao F. Triplenegative breast cancer: investigating potential molecular therapeutic target. Expert Opin Ther Targets. 2015;19(1):55-75.

38. Arnedos M, Bihan C, Delaloge S, Andre F. Triple-negative breast cancer: are we making headway at least? Ther Adv Med Oncol. 2012; 4(4):195-210.

39. Onder TT, Gupta PB, Mani SA, Yang J, Lander ES, Weinberg RA. Loss of E-cadherin promotes metastasis via multiple downstream transcriptional pathways. Cancer Res. 2008;68(10):3645-3654.
40. Derksen PW, Liu X, Saridin F, et al. Somatic inactivation of E-cadherin and p53 in mice leads to metastatic lobular mammary carcinoma through induction of anoikis resistance and angiogenesis. Cancer Cell. 2006;10(5):437-449.

41. Gupton SL, Waterman-Storer CM. Spatiotemporal feedback between actomyosin and focal-adhesion systems optimizes rapid cell migration. Cell. 2006;125(7):1361-1374.

42. Golubovskaya VM, Ylagan L, Miller A, et al. High focal adhesion kinase expression in breast carcinoma is associated with lymphovascular invasion and triple-negative phenotype. BMC Cancer. 2014;14:769.

43. Yom CK, Noh DY, Kim WH, Kim HS. Clinical significance of high focal adhesion kinase gene copy number and overexpression in invasive breast cancer. Breast Cancer Res Treat. 2011;128(3):647-655.

44. Murakami E, Nakanishi Y, Hirotani Y, et al. Roles of Ras homolog A in invasive ductal breast carcinoma. Acta Histochem Cytochem. 2016; 49(5):131-140.

45. Bellizzi A, Mangia A, Chiriatti A, et al. RhoA protein expression in primary breast cancers and matched lymphocytes is associated with progression of the disease. Int J Mol Med. 2008;22(1):25-31.

46. Yamaguchi H, Condeelis J. Regulation of the actin cytoskeleton in cancer cell migration and invasion. Biochim Biophys Acta. 2007; 1773(5):642-652.

47. Olson MF, Sahai E. The actin cytoskeleton in cancer cell motility. Clin Exp Metastasis. 2009;26(4):273-287.

48. Kanchanawong P, Shtengel G, Pasapera AM, et al. Nanoscale architecture of integrin-based cell adhesions. Nature. 2010;468(7323):580-584.

49. Horton ER, Byron A, Askari JA, et al. Definition of a consensus integrin adhesome and its dynamics during adhesion complex assembly and disassembly. Nat Cell Biol. 2015;17(12):1577-1587.

50. Uhlén M, Fagerberg L, Hallström BM, et al. Proteomics. Tissue-based map of the human proteome. Science. 2015;347(6220):1260419.

51. Gao J, Aksoy BA, Dogrusoz U, et al. Integrative analysis of complex cancer genomics and clinical profiles using the cBioPortal. Sci Signal. 2013;2:6(269):1. 


\section{Supplementary materials}

Table SI Differentially expressed genes between low vs high expressions of AIFIL gene in CCLE breast cell database

\begin{tabular}{|c|c|c|c|}
\hline Name & $\begin{array}{l}\text { Gene } \\
\text { symbol }\end{array}$ & Gene_title & Score \\
\hline FOSLI & FOSLI & FOS-like antigen I & 0.837046 \\
\hline EMP3 & EMP3 & Epithelial membrane protein 3 & 0.802068 \\
\hline ZDHHC2 & ZDHHC2 & Zinc finger, DHHC-type containing 2 & 0.790615 \\
\hline AXL & $A X L$ & $A X L$ receptor tyrosine kinase & 0.781382 \\
\hline IGFBP7 & IGFBP7 & Insulin-like growth factor binding protein 7 & $0.7696 \mathrm{I}$ \\
\hline SERPINEI & SERPINEI & Serpin peptidase inhibitor, clade E (nexin, plasminogen activator inhibitor type I), member I & 0.75092 \\
\hline COL4A2 & COL4A2 & Collagen, type IV, alpha 2 & 0.746052 \\
\hline TGFBIII & TGFB III & Transforming growth factor beta I induced transcript I & 0.729768 \\
\hline IGFBP6 & IGFBP6 & Insulin-like growth factor binding protein 6 & 0.725726 \\
\hline COL4AI & COL4AI & Collagen, type IV, alpha I & 0.707212 \\
\hline $\mathrm{HRHI}$ & $\mathrm{HRHI}$ & Histamine receptor $\mathrm{HI}$ & 0.690314 \\
\hline BCATI & BCATI & Branched chain aminotransferase I, cytosolic & 0.685178 \\
\hline PROCR & PROCR & Protein C receptor, endothelial (EPCR) & 0.684549 \\
\hline COL6A2 & COL6A2 & Collagen, type VI, alpha 2 & 0.667416 \\
\hline PHLDAI & PHLDAI & Pleckstrin homology-like domain, family A, member I & 0.667399 \\
\hline SLFNI 2 & SLFN $/ 2$ & Schlafen family member 12 & 0.663343 \\
\hline RAB34 & RAB34 & RAB34, member RAS oncogene family & 0.646708 \\
\hline PLAU & PLAU & Plasminogen activator, urokinase & 0.640417 \\
\hline AKAPI 2 & AKAPI 2 & A kinase (PRKA) anchor protein (gravin) 12 & 0.630199 \\
\hline DFNA5 & DFNA5 & Deafness, autosomal dominant 5 & 0.629837 \\
\hline LHFP & LHFP & Lipoma HMGIC fusion partner & $0.62757 \mid$ \\
\hline SPOCKI & SPOCKI & Sparc/osteonectin, cwcv and kazal-like domains proteoglycan (testican) I & 0.622842 \\
\hline FAMIOIB & FAMIOIB & Family with sequence similarity 101 , member $B$ & 0.619061 \\
\hline COL6AI & COL6AI & Collagen, type VI, alpha I & 0.611874 \\
\hline ADAMI9 & ADAM 19 & ADAM metallopeptidase domain 19 (meltrin beta) & 0.610056 \\
\hline COL5A2 & COL5A2 & Collagen, type $\mathrm{V}$, alpha 2 & 0.607276 \\
\hline TIMPI & TIMPI & TIMP metallopeptidase inhibitor I & 0.606783 \\
\hline SCG2 & SCG2 & Secretogranin II (chromogranin C) & 0.60473 \\
\hline NOV & NOV & Nephroblastoma overexpressed gene & 0.604233 \\
\hline TMEMI58 & TMEM 158 & Transmembrane protein 158 & 0.603507 \\
\hline DKK3 & DKK3 & Dickkopf homolog 3 (Xenopus laevis) & 0.602322 \\
\hline PRRI6 & PRRI6 & Proline rich 16 & 0.599183 \\
\hline IL6 & IL6 & Interleukin 6 (interferon, beta 2) & 0.598937 \\
\hline LIF & LIF & Leukemia inhibitory factor (cholinergic differentiation factor) & 0.597241 \\
\hline FGF2 & FGF2 & Fibroblast growth factor 2 (basic) & 0.596823 \\
\hline TNFAIP3 & TNFAIP3 & Tumor necrosis factor, alpha-induced protein 3 & 0.595126 \\
\hline GLIS3 & GLIS3 & GLIS family zinc finger 3 & 0.594521 \\
\hline EPHA2 & EPHA2 & EPH receptor $\mathrm{A} 2$ & 0.593322 \\
\hline NT5E & NT5E & $5^{\prime}$-nucleotidase, ecto (CD73) & 0.586506 \\
\hline TMEM22 & TMEM22 & Transmembrane protein 22 & 0.586264 \\
\hline FYN & FYN & FYN oncogene related to SRC, FGR, YES & 0.584119 \\
\hline PTRF & PTRF & Polymerase I and transcript release factor & 0.583833 \\
\hline MMP2 & MMP2 & Matrix metallopeptidase 2 (gelatinase A, 72 kDa gelatinase, $72 \mathrm{kDa}$ type IV collagenase) & 0.583674 \\
\hline TMEMI33 & TMEM /33 & Transmembrane protein I33 & $0.58260 \mathrm{I}$ \\
\hline PTPRM & PTPRM & Protein tyrosine phosphatase, receptor type, $M$ & 0.580363 \\
\hline IGF2BP3 & IGF2BP3 & Insulin-like growth factor 2 mRNA binding protein 3 & 0.57938 \\
\hline FBNI & FBNI & Fibrillin I & 0.576254 \\
\hline CAVI & CAVI & Caveolin I, caveolae protein, $22 \mathrm{kDa}$ & 0.575581 \\
\hline $\mathrm{CDH} 2$ & $\mathrm{CDH} 2$ & Cadherin 2, type I, N-cadherin (neuronal) & 0.573586 \\
\hline FSTLI & FSTLI & Follistatin-like I & 0.571101 \\
\hline FGFI3 & FGFI3 & Fibroblast growth factor 13 & -0.44624 \\
\hline CYP4XI & CYP4XI & Cytochrome P450, family 4, subfamily X, polypeptide I & $-0.4488 \mathrm{I}$ \\
\hline
\end{tabular}


Table SI (Continued)

\begin{tabular}{|c|c|c|c|}
\hline Name & $\begin{array}{l}\text { Gene_ } \\
\text { symbol }\end{array}$ & Gene_title & Score \\
\hline PRSS8 & PRSS8 & Protease, serine 8 (prostasin) & -0.44885 \\
\hline HRASLS & HRASLS & HRAS-like suppressor & -0.4543 \\
\hline $\mathrm{CDHI}$ & $\mathrm{CDHI}$ & Cadherin I, type I, E-cadherin (epithelial) & -0.45663 \\
\hline SYCP2 & SYCP2 & Synaptonemal complex protein 2 & -0.45812 \\
\hline ZNFI38 & ZNFI38 & Zinc finger protein 138 & -0.45815 \\
\hline REPS2 & REPS2 & RALBPI-associated Eps domain containing 2 & -0.46265 \\
\hline Cl9orf46 & CI9ORF46 & Chromosome 19 open reading frame 46 & -0.46353 \\
\hline VTCNI & VTCNI & V-set domain containing $T$ cell activation inhibitor I & -0.46819 \\
\hline Clorfl72 & CIORFI 72 & Chromosome I open reading frame 172 & -0.46911 \\
\hline MAPT & MAPT & Microtubule-associated protein tau & -0.47075 \\
\hline IGSF9 & IGSF9 & Immunoglobulin superfamily, member 9 & -0.47255 \\
\hline C9orfl52 & C9ORFI52 & Chromosome 9 open reading frame 152 & -0.47257 \\
\hline RAB25 & RAB25 & RAB25, member RAS oncogene family & -0.4732 \\
\hline KIAAI324 & KIAA/324 & KIAAI 324 & -0.4738 \\
\hline FOXAI & FOXAI & Forkhead box Al & -0.47381 \\
\hline SPDEF & SPDEF & SAM pointed domain containing ets transcription factor & -0.47942 \\
\hline REEPI & REEPI & Receptor accessory protein I & -0.48044 \\
\hline CGN & CGN & Cingulin & -0.48205 \\
\hline OAZ3 & OAZ3 & Ornithine decarboxylase antizyme 3 & -0.48362 \\
\hline MB & $M B$ & myoglobin & -0.48515 \\
\hline NEBL & NEBL & Nebulette & -0.48792 \\
\hline ST6GALI & ST6GALI & ST6 beta-galactosamide alpha-2,6-sialyltranferase I & -0.49266 \\
\hline ALDH3B2 & $A L D H 3 B 2$ & Aldehyde dehydrogenase 3 family, member B2 & -0.49449 \\
\hline CLDN4 & CLDN4 & Claudin 4 & -0.49664 \\
\hline LOCI00506497 & Null & Null & -0.50289 \\
\hline GRHL2 & GRHL2 & Grainyhead-like 2 (Drosophila) & -0.50291 \\
\hline CLDN3 & CLDN3 & Claudin 3 & -0.50757 \\
\hline ZNF467 & ZNF467 & Zinc finger protein 467 & -0.50862 \\
\hline SIDTI & SIDTI & SIDI transmembrane family, member I & -0.51057 \\
\hline CEBPA & CEBPA & CCAAT/enhancer binding protein (C/EBP), alpha & -0.51303 \\
\hline BSPRY & BSPRY & B-box and SPRY domain containing & -0.51612 \\
\hline RASEF & RASEF & RAS and EF-hand domain containing & -0.5214 \\
\hline IRX5 & IRX5 & Iroquois homeobox protein 5 & -0.52766 \\
\hline EPN3 & EPN3 & Epsin 3 & -0.53665 \\
\hline EFNA3 & EFNA3 & Ephrin-A3 & -0.54208 \\
\hline SELENBPI & SELENBPI & Selenium binding protein I & -0.54401 \\
\hline GLYATL2 & GLYATL2 & Glycine- $\mathrm{N}$-acyltransferase-like 2 & -0.54889 \\
\hline GRHLI & GRHLI & Grainyhead-like I (Drosophila) & -0.5533 \\
\hline CRABP2 & CRABP2 & Cellular retinoic acid binding protein 2 & -0.55677 \\
\hline HEY2 & HEY2 & Hairy/enhancer-of-split related with YRPW motif 2 & -0.56036 \\
\hline TFAP2C & TFAP2C & Transcription factor AP-2 gamma (activating enhancer binding protein 2 gamma) & -0.5666 \\
\hline RERG & RERG & RAS-like, estrogen-regulated, growth inhibitor & -0.56686 \\
\hline SYTI2 & SYTI2 & Synaptotagmin XII & -0.57878 \\
\hline CYP4ZI & CYP4ZI & Cytochrome P450, family 4, subfamily Z, polypeptide I & -0.61774 \\
\hline EFHDI & EFHDI & EF-hand domain family, member DI & -0.62168 \\
\hline PRLR & PRLR & Prolactin receptor & -0.62633 \\
\hline MYB & MYB & v-myb myeloblastosis viral oncogene homolog (avian) & -0.6605 \\
\hline VAV3 & VAV3 & vav 3 oncogene & -0.75064 \\
\hline
\end{tabular}

Abbreviation: CCLE, Cancer Cell Line Encyclopedia. 
Table S2 The most affected genes in the HSA045I0_FOCAL_ADHESION pathway

\begin{tabular}{|c|c|c|c|c|c|}
\hline Name & $\begin{array}{l}\text { Gene } \\
\text { symbol }\end{array}$ & Gene_title & $\begin{array}{l}\text { Rank in } \\
\text { gene list }\end{array}$ & $\begin{array}{l}\text { Rank metric } \\
\text { score }\end{array}$ & Running es \\
\hline row_0 & COL4A2 & Collagen, type IV, alpha 2 & 6 & 0.746052 & 0.024102 \\
\hline row_l & COL4AI & Collagen, type IV, alpha I & 9 & 0.707211 & $0.047 \mid 46$ \\
\hline row_2 & COL6A2 & Collagen, type $\mathrm{VI}$, alpha 2 & 13 & 0.667416 & 0.068834 \\
\hline row_3 & COL6AI & Collagen, type VI, alpha I & 25 & 0.611874 & 0.088276 \\
\hline row_4 & COL5A2 & Collagen, type $\mathrm{V}$, alpha 2 & 27 & 0.607276 & 0.108102 \\
\hline row_5 & FYN & FYN oncogene related to SRC, FGR, YES & 45 & 0.584118 & 0.126316 \\
\hline row_6 & CAVI & Caveolin I, caveolae protein, 22 kDa & 52 & $0.57558 \mid$ & 0.144838 \\
\hline row_7 & VEGFC & Vascular endothelial growth factor C & 72 & 0.553132 & 0.161931 \\
\hline row_8 & COLIA2 & Collagen, type I, alpha 2 & 81 & 0.540925 & 0.179211 \\
\hline row_9 & AKT3 & v-akt murine thymoma viral oncogene homolog 3 (protein kinase B, gamma) & 117 & 0.493746 & 0.193506 \\
\hline row_10 & ITGA4 & Integrin, alpha 4 (antigen CD49D, alpha 4 subunit of VLA-4 receptor) & 145 & 0.472133 & 0.20752 \\
\hline row_II & FLNC & Filamin C, gamma (actin binding protein 280) & 200 & 0.44223 & 0.219114 \\
\hline row_12 & LAMC2 & Laminin, gamma 2 & 203 & 0.441652 & 0.233465 \\
\hline row_13 & CAV2 & Caveolin 2 & 215 & 0.436721 & 0.247174 \\
\hline row_14 & LAMA4 & Laminin, alpha 4 & 225 & 0.433796 & 0.260894 \\
\hline row_15 & $\mathrm{BIRC3}$ & Baculoviral IAP repeat-containing 3 & 226 & $0.433 \mid 45$ & 0.275073 \\
\hline row_16 & ITGA3 & Integrin, alpha 3 (antigen CD49C, alpha 3 subunit of VLA-3 receptor) & 235 & 0.427453 & 0.288639 \\
\hline row_17 & ITGA5 & Integrin, alpha 5 (fibronectin receptor, alpha polypeptide) & 241 & $0.425 \mid 45$ & 0.302289 \\
\hline row_18 & COL3AI & Collagen, type III, alpha I (Ehlers-Danlos syndrome type IV, autosomal dominant) & 278 & 0.406763 & 0.313683 \\
\hline row_19 & ITGA6 & Integrin, alpha 6 & 282 & 0.405993 & 0.326814 \\
\hline row_20 & LAMB3 & Laminin, beta 3 & 287 & 0.403633 & 0.339813 \\
\hline row_21 & PDGFC & Platelet-derived growth factor $\mathrm{C}$ & 299 & 0.400535 & 0.352338 \\
\hline row_22 & LAMCI & Laminin, gamma I (formerly LAMB2) & 346 & 0.382794 & 0.362413 \\
\hline row_23 & $\mathrm{FNI}$ & Fibronectin I & 360 & 0.376867 & 0.374056 \\
\hline row_24 & COL5AI & Collagen, type V, alpha I & 365 & 0.375251 & $0.386 \mid 27$ \\
\hline row_25 & MYL9 & Myosin, light chain 9, regulatory & 369 & 0.373747 & 0.398201 \\
\hline row_26 & MYLK & Myosin, light chain kinase & 387 & 0.368815 & 0.409367 \\
\hline row_27 & PDGFA & Platelet-derived growth factor alpha polypeptide & 501 & 0.33853 & $0.4144 \mid 8$ \\
\hline row_28 & PIK3CD & Phosphoinositide-3-kinase, catalytic, delta polypeptide & 531 & 0.329876 & 0.423668 \\
\hline row_29 & $L A M B I$ & Laminin, beta I & 532 & 0.329803 & 0.434465 \\
\hline row_30 & PRKCA & Protein kinase C, alpha & 533 & 0.329702 & 0.445257 \\
\hline row_31 & COLIAI & Collagen, type I, alpha I & 536 & 0.329197 & 0.455927 \\
\hline row_32 & ITGB4 & Integrin, beta 4 & 581 & 0.321616 & 0.464107 \\
\hline row_33 & LAMA2 & Laminin, alpha 2 (merosin, congenital muscular dystrophy) & 586 & 0.320621 & 0.474389 \\
\hline row_34 & COL6A3 & Collagen, type VI, alpha 3 & 588 & 0.32032 & 0.484821 \\
\hline row_35 & MET & met proto-oncogene (hepatocyte growth factor receptor) & 604 & 0.316587 & 0.494384 \\
\hline row_36 & THBSI & Thrombospondin I & 698 & 0.297631 & 0.499164 \\
\hline row_37 & COL4A6 & Collagen, type IV, alpha 6 & 749 & 0.288689 & 0.505945 \\
\hline row_38 & SPPI & $\begin{array}{l}\text { Secreted phosphoprotein I (osteopontin, bone sialoprotein I, early } \\
\text { T-lymphocyte activation I) }\end{array}$ & 782 & 0.281494 & 0.513452 \\
\hline row_39 & LAMB2 & Laminin, beta 2 (laminin S) & 838 & 0.268912 & 0.519319 \\
\hline row_40 & PARVA & Parvin, alpha & 880 & 0.259453 & 0.525624 \\
\hline row_4l & PDGFRB & Platelet-derived growth factor receptor, beta polypeptide & 915 & 0.25332 & 0.532102 \\
\hline row_42 & PGF & Placental growth factor, vascular endothelial growth factor-related protein & 998 & 0.241213 & 0.535622 \\
\hline row_43 & ACTNI & Actinin, alpha I & I,007 & 0.240274 & 0.54306 \\
\hline row_44 & TNC & Tenascin C (hexabrachion) & 1,012 & 0.239859 & 0.550698 \\
\hline row_45 & FLNA & Tilamin A, alpha (actin-binding protein 280 ) & 1,066 & 0.23099 & 0.555431 \\
\hline row_46 & RAC2 & $\begin{array}{l}\text { ras-related C } 3 \text { botulinum toxin substrate } 2 \text { (rho family, small GTP binding } \\
\text { protein Rac2) }\end{array}$ & ।,087 & 0.227534 & 0.561812 \\
\hline row_47 & PARVB & Parvin, beta & 1,129 & 0.222995 & 0.566924 \\
\hline row_48 & TLNI & Talin I & 1,239 & 0.209093 & $0.56795 I$ \\
\hline row_49 & $V C L$ & Vinculin & 1,253 & 0.2071 & 0.574036 \\
\hline row_50 & $Z Y X$ & Zyxin & I,275 & 0.204779 & 0.579619 \\
\hline row_5I & COL5A3 & Collagen, type V, alpha 3 & 1,409 & 0.19049 & 0.578756 \\
\hline row_52 & $P X N$ & Paxillin & I,482 & 0.184277 & 0.580945 \\
\hline row_53 & COLIIAI & Collagen, type XI, alpha I & 1,517 & 0.180528 & 0.58504 \\
\hline
\end{tabular}


Table S2 (Continued)

\begin{tabular}{|c|c|c|c|c|c|}
\hline Name & $\begin{array}{l}\text { Gene_- } \\
\text { symbol }\end{array}$ & Gene_title & $\begin{array}{l}\text { Rank in } \\
\text { gene list }\end{array}$ & $\begin{array}{l}\text { Rank metric } \\
\text { score }\end{array}$ & Running es \\
\hline row_54 & CAPN2 & Calpain 2, (m/ll) large subunit & $\mathrm{I}, 554$ & 0.176329 & 0.588891 \\
\hline row_55 & LAMAI & Laminin, alpha I & 1,609 & 0.170144 & 0.591579 \\
\hline row_56 & ACTN4 & Actinin, alpha 4 & $\mathrm{I}, 645$ & 0.16764 & 0.595198 \\
\hline row_57 & ITGAV & Integrin, alpha $V$ (vitronectin receptor, alpha polypeptide, antigen CD5I) & $\mathrm{I}, 728$ & 0.160049 & 0.596061 \\
\hline row_58 & PDGFRA & Platelet-derived growth factor receptor, alpha polypeptide & $\mathrm{I}, 742$ & 0.158875 & 0.600568 \\
\hline row_59 & ITGA8 & Integrin, alpha 8 & $\mathrm{I}, 754$ & 0.158028 & $0.605 I 54$ \\
\hline row_60 & SHC3 & SHC (Src homology 2 domain containing) transforming protein 3 & $\mathrm{I}, 763$ & 0.157112 & 0.60987 \\
\hline row_6l & ITGA I I & Integrin, alpha II & $\mathrm{I}, 768$ & 0.15679 & 0.614789 \\
\hline row_62 & $\mathrm{SHCl}$ & SHC transforming protein I & 1,818 & 0.153003 & 0.617182 \\
\hline row_63 & THBS2 & Thrombospondin 2 & $\mathrm{I}, 826$ & 0.152263 & 0.621793 \\
\hline row_64 & CCNDI & Cyclin DI & $\mathrm{I}, 879$ & 0.149562 & $0.6239 \mid 4$ \\
\hline row_65 & ITGA2 & Integrin, alpha 2 (CD49B, alpha 2 subunit of VLA-2 receptor) & $\mathrm{I}, 88 \mathrm{I}$ & 0.14919 & 0.628744 \\
\hline
\end{tabular}

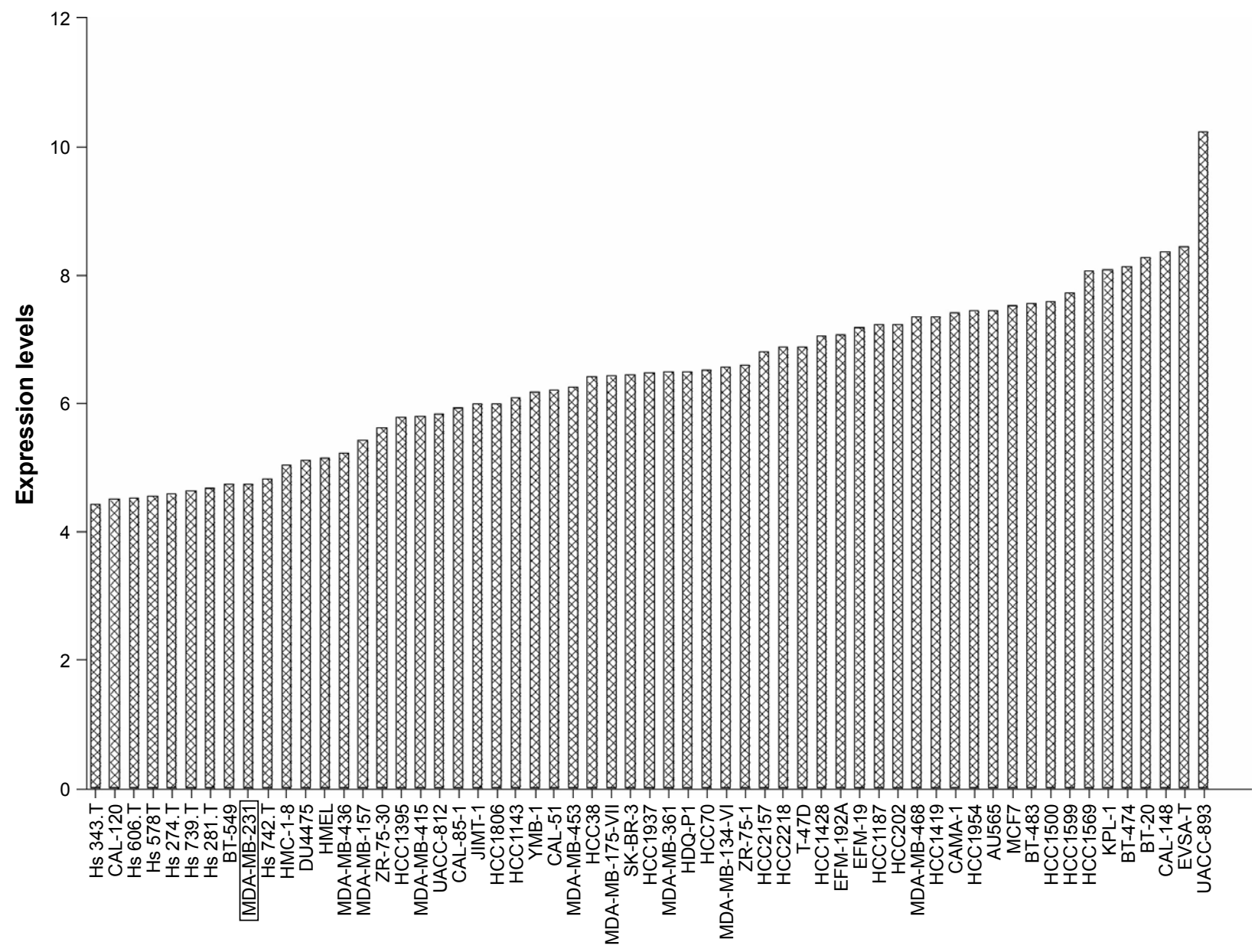

Figure SI AIFIL expression levels in the breast cell of CCLE.

Note: Rectangle around MDA-MB-23I shows indicates AIFIL expression level was lower in MDA-MB-23I cell.

Abbreviation: CCLE, Cancer Cell Line Encyclopedia.

OncoTargets and Therapy

\section{Publish your work in this journal}

OncoTargets and Therapy is an international, peer-reviewed, open access journal focusing on the pathological basis of all cancers, potential targets for therapy and treatment protocols employed to improve the management of cancer patients. The journal also focuses on the impact of management programs and new therapeutic agents and protocols on patient perspectives such as quality of life, adherence and satisfaction. The manuscript management system is completely online and includes a very quick and fair peer-review system, which is all easy to use. Visit $\mathrm{http}: / / \mathrm{www}$.dovepress.com/testimonials.php to read real quotes from published authors. 